\title{
Long Term Pulmonary Toxicity of Indium Arsenide and Indium Phosphide Instilled Intratracheally in Hamsters
}

\author{
Koji Yamazaki ${ }^{1,2}$, Akiyo Tanaka ${ }^{1}$, Miyuki Hirata ${ }^{1}$, Minoru Omura ${ }^{1}$, Yuji Makita ${ }^{1}$, \\ Naohide Inoue', Kenji Sugro², Keizo SuglmaChI ${ }^{2}$ \\ 'Department of Hygiene and \\ 2Department of Surgery and Science, Graduate School of Medical Sciences, Kyushu University
}

\begin{abstract}
Long Term Pulmonary Toxicity of Indium Arsenide and Indium Phosphide Instilled Intratracheally in Hamsters: Koji YAMAZAKI, et al. Department of Hygiene, Graduate School of Medical Sciences, Kyushu University-We examined the long-term toxicological effects of III-V semiconductor particles on laboratory animals. Eight-week-old male Syrian golden hamsters were given $4 \mathrm{mg} / \mathrm{kg}$ indium arsenide (InAs) or $3 \mathrm{mg} / \mathrm{kg}$ indium phosphide $(\ln \mathrm{P})$ particles, both containing $2.4 \mathrm{mg} / \mathrm{kg}$ as indium, intratracheally twice a week for 8 weeks. Control hamsters were given only a vehicle, phosphate buffer solution. Over a $2-y r$ period, these animals were euthanized serially and the biological effects were determined. Weight gain was significantly suppressed in both InAs and InP groups, compared to the control group, with greater suppression in the InAs group. The serum indium concentration in the InAs group was about twice as high as that in the InP group, in each period. Histopathologically, severe pulmonary inflammation and localized lesions with bronchioloalveolar cell hyperplasia were present in both $\operatorname{InAs}$ and InP groups from just after the last administration. The localized lesions gradually transformed to proteinosislike lesions with periodic acid Schiff reagent positive exudation after $16 \mathrm{wk}$. By means of immunostaining of proliferating cell nuclear antigen and argyrophilic proteins associated with nucleolar organizer regions staining, proliferative activities were evidenced in the localized lesions at each time and were noticeable in their early stage. K-ras, a known oncogene, was not mutated in association with these lesions. In conclusion, InAs and InP particles caused severe systemic toxicity and pulmonary localized hyperplastic lesions with proliferative activity were derived via the respiratory route. Neoplastic change was nil even in a
\end{abstract}

Received Jan 18.2000; Accepted March 14, 2000

Correspondence to: K. Yamazaki, Department of Surgerv and

Science, Graduate School of Medical Sciences, Kyushu Universit:

3-1-1 Maidashi, Higashi-ku, Fukuoka 812-8582, Japan 2-yr observation period

(J Occup Health 2000; 42: 169-178)

Key words: semiconductor materials, indium arsenide, indium phosphide, intratracheal instillation, pulmonary toxicity, proliferative activity

Indium arsenide (InAs) and indium phosphide (InP) belong to the III- $\mathrm{V}$ semiconductor compounds that are widely used in the semiconductor industry as they possess superior electronic properties. ${ }^{1.21}$. With increasing use of these materials, health hazards to workers at semiconductor factories as well as environmental pollution have to be given attention. In the case of workers, the primary route of exposure would be direct inhalation. Chronic toxicity may be an urgent health hazard to be addressed because exposure to such materials may lead to accumulation in the body. There are numerous data on laboratory animals concerning the toxicity of gallium arsenide (GaAs), one of the most widely used semiconductor materials $s^{2-6)}$ and data on the biological effects of $\operatorname{In} A s^{7.81}$ and $\operatorname{In} \mathrm{P}^{4-121}$ have recently appeared.

When the biological effects of semiconductor compounds are assessed, the toxicity of arsenic has been mainly focused on, whereas constitutive elements are considerably related to the effects and it is necessary to investigate their toxicities. We investigated a subacute toxicity of $7.7 \mathrm{mg} / \mathrm{kg}$ of InAs and GaAs and $1.3 \mathrm{mg} / \mathrm{kg}$ of arsenic trioxide $\left(\mathrm{As}_{2} \mathrm{O}_{3}\right)$ by repeated intratracheal instillation of these agents into Syrian golden hamsters for 7 or $8 \mathrm{wk}^{13-15)}$. Pulmonary inflammation was severe and localized lesions of bronchiolo-alveolar cell hyperplasia with metaplasia and squamous cell hyperplasia were frequent in the lungs of InAs-treated hamsters but not in $\mathrm{GaAs}$ or $\mathrm{As}_{2} \mathrm{O}_{3}$-treated hamsters. We therefore considered that indium, not arsenic, probably accounted for most of the changes in the lungs. To elucidate which element, indium or arsenic, plays the main role in long-term systemic 
and pulmonary toxicity of InAs, equimolar InP was also used. We focused on the characterization of pulmonary hyperplastic lesions, especially proliferation and neoplastic potency. InAs was given at about half the dose used in the earlier studies because severe emaciation occurred and long-term observation was not feasible ${ }^{15]}$. This is the first report on the long term biological effects of indium compounds instilled intratracheally.

\section{Materials and Methods}

\section{Test materials}

InAs and InP, over $99.99 \%$ pure and provided by Mitsuwa Chemicals (Osaka, Japan) were finely pulverized in an agate mortar and the mean count diameter for In As and InP was $1.58 \mu \mathrm{m}$ [ $\sigma \mathrm{g}$ (geometric standard deviation): 2.15 ] and $1.06 \mu \mathrm{m}$ [ $\sigma \mathrm{g}: 1.80]$. Both powders were analyzed in an energy dispersive X-ray fluorescence element analyzer (MESA-500, Horiba, Ltd., Kyoto, Japan). InAs powder contained $0.01 \%$ (wt $\%$ ) of zirconium and $0.01 \%$ of yttrium, and InP powder contained $0.01 \%$ of zirconium and a trace amount of yttrium. In particulate form, these compounds were suspended aseptically in pathogen-free $0.025 \mathrm{M}$ phosphate buffer solution (PBS), pH 6.86 just before each instillation.

\section{Animals}

Weanling male 6 week-old Syrian golden hamsters were purchased from Japan SLC, Inc., (Shizuoka, Japan) and housed under conditions of controlled temperature of between 22 and $25^{\circ} \mathrm{C}$. All the animals were maintained on a cycle of 12-h lighting conditions in a specific pathogen-free laboratory room of the Laboratory of Animal Experiments, Faculty of Medicine, Kyushu University. Four hamsters were housed in one stainless cage with diets (CE-2 pellets, Clea Japan, Inc., Tokyo, Japan) and tap water freely available. After they had acclimated to the animal facility for $2 \mathrm{wk}$ before the start of the experiment, 144 eight week-old hamsters, with a mean \pm SD weight of $110.87 \pm 7.22 \mathrm{~g}$, were randomized into 3 groups by weight: the InAs group, the InP group and the control group. There was no significant difference in body weight among groups at the start of the experiment.

\section{Intratracheal instillation of materials}

The concentrations of InAs and InP suspensions were $2.0 \mathrm{mg} / \mathrm{m} /$ and $1.5 \mathrm{mg} / \mathrm{m} l$, respectively. As a single dose, each group was given an intratracheal instillation in a volume of $2.0 \mathrm{~m} l / \mathrm{kg}$ suspension, containing equimolar particles, $21.08 \mu \mathrm{mol} / \mathrm{kg}$ of InAs $(4.0 \mathrm{mg} / \mathrm{kg}$ ) or 20.58 $\mu \mathrm{mol} / \mathrm{kg}$ of InP $(3.0 \mathrm{mg} / \mathrm{kg})$, whereas the control group were given PBS only. For the intratracheal instillations, we used the methods of Ishinishi ef $a{ }^{161}$ Before each instillation, the hamsters were given $0.1 \mathrm{~m} /$ of atropine sulfate subcutaneously and anesthetized inside a desiccator filled with diethyl ether gas. Suspensions of particles were instilled into the trachea of the hamsters by means of a microsyringe with a special metal needle. The hamsters were thus treated twice weekly for 8 wk.

\section{Autopsy of animals and tissue sampling}

After $0,8,16,40,64$ and $88 \mathrm{wk}$ of treatment, 4-8 hamsters in each group were weighed and deeply anesthetized with ether. Total blood taken from the posterior vena cava was centrifuged into serum. Resected lungs were weighed and fixed in $10 \%$ neutral buffered formalin for 20 to $24 \mathrm{~h}$ and processed in paraffin. Specimens were cut at a thickness of $6 \mu \mathrm{m}$ and mounted on microscopic glass slides. Each section was stained with hematoxylin and eosin and periodic acid Schiff reagent (PAS). When localized lesions of bronchioloalveolar cell hyperplasia were evident, the same sections were newly cut and assessed, for proliferating cell nuclear antigen (PCNA), argyrophilic proteins associated with nucleolar organizer regions (AgNORs) and the mutation status of the K-ras gene.

Quantifying of indium and arsenic in the sera by inductively coupled plasma mass spectrometry (ICP-MS)

Serum samples were stored at $-80^{\circ} \mathrm{C}$ until analysis. They were prepared for analyis by diluting a $200 \mu$ sample with $9.8 \mathrm{~m} /$ of $0.4 \% \mathrm{HNO}_{3}$. Each sample contained yttrium at $20 \mathrm{ng} / \mathrm{ml}$ as an internal standard. Indium and arsenic were quantified for all samples with aqueous standard solutions in $0.4 \% \mathrm{HNO}_{3}$ with ELAN 5000 ICP-MS (Perkin Elmer Japan).

\section{Immunohistochemical staining of PCNA}

Selected tissue sections containing pulmonary localized lesions were stained for $\mathrm{PCNA}^{17}$, by a standard immunoperoxidase method and the avidin-biotinperoxidase complex $^{18.191}$. Monoclonal mouse anti-PCNA antibody (PC10, Santa Cruz Biotechnology, Inc., California, USA) was used for detection of the antigen at 1:100 dilution, overnight at $4^{\circ} \mathrm{C}$. Staining was completed with a 5 -min incubation in the substrate $0.03 \% 3,3^{\prime}$ diaminobenzidine in $0.05 \mathrm{M}$ Tris buffer ( $\mathrm{pH} 7.6$ ) containing $0.04 \%$ hydrogen peroxide. Immunostaining was interpreted independently by two different observers. Expression of PCNA was confined to the nuclei of the localized lesions and nuclear stainings were scored based on the labeling index (L.I. $)^{20}$.

\section{AgNORs staining}

Pulmonary localized lesions were also stained for AgNORs, as described ${ }^{211}$. Discrete dots in at least 100 cells in each lesion ${ }^{22.23)}$ were counted and scored based on the average. As a control, we cvaluated the AgNORs count of normal alveolar epithelium in the lungs of the control group. 
DNA extraction from specimens on slides and PCR with designed restriction fragment polymorphism (RFLP) analysis to detect $K$-ras mutation

Pulmonary localized lesions were collected from paraffinized mounted sections, by a microdissection technique ${ }^{2+t}$. The materials collected were digested with proteinase K to extract DNAs. The final concentrations of samples were at least $100 \mathrm{cells} / \mu$.

Mutations in codons 12 and 13 of the K-ras gene were examined by hemi-nested PCR methods ${ }^{2+}, 25$. The first $P C R$ reaction was performed in a $50 \mu$ reaction mixture containing $5 \mu$ template DNA prepared as above. The first PCR product was diluted 1:50 in distilled deionized water and $1 \mu l$ of the dilution was used as a template in a 20 $\mu l$ reaction mixture of the second PCR. The primers were previously designed ${ }^{2+, 251}$ to establish new restriction sites into the final PCR product derived from a wild-type allele. Fifteen $\mu l$ of the second PCR product was digested with 8-10 units of one of the specific restriction enzymes, $B s t$ NI for codon 12 and $B g /$ for codon 13 , under conditions recommended by the suppliers (NEW ENGLAND Biolabs Inc., Beverly, USA). The digested products were always run with lymphocytes collected individually and simultaneously, as negative controls, and complete digestion was confirmed. The final products were electrophoresed with 100 base DNA ladder (Takara BIOCHEMICALS, Shiga. Japan) and visualized by UV light after ethidium bromide staining. As mutant alleles were not digested by specific restriction enzymes, they appeared larger than the digested wild-type bands.

\section{Statistical analvsis}

Data on body weight were analyzed by repeated measure-ANOVA. Data on serum concentration of materials and proliferating levels were analyzed by the Mann-Whitney Test. A p-value below a level of 0.05 was considered to have statistical significance. Data are given as the mean \pm standard deviation (SD).

\section{Results}

Sustemic effects

Sixteen intratracheal instillations led to a mean total amount of particles per animal of $7.89 \pm 0.58 \mathrm{mg}$ in the In As group and $6.04 \pm 0.40 \mathrm{mg}$ in the InP group. containing $4.77 \pm 0.35 \mathrm{mg}$ and $4.75 \pm 0.32 \mathrm{mg}$ of indium. respectively.

No hamsters died during the administration period and animals which died during the observation period were excluded from all evaluations. In the control group, 4 were killed accidentally and 4 were cannibalized. Five died of emaciation and 3 were cannibalized in the $\ln$ As group and 3 of emaciation in the InP group. Finally, 40 animals in the control group, 40 in the InAs group and 45 in the InP group were examined, as scheduled. At least 4 hamsters in each group were examined at each time during the experiment.

Intratracheal instillations of InAs and InP led to a marked suppression of body weight gain. Fig. IA shows the body weight of whole animals during the administration period. The body weight of the InAs and InP groups gradually decreased from $5 \mathrm{wk}$ of the administration period and the InAs group showed a greater inhibition of body weight gain than did the InP group. Significant differences in trends of body weight change were found between groups.

Trends in body weight change throughout the observation period are shown in Fig. IB, for animals observed until $88 \mathrm{wk}$ (5 animals in the InAs group, 4 in the InP group and 4 in the control). The difference in trends of body weight changes between the InAs group and the control group was significant $(p<0.0001)$. Eight wk after the end of treatment, body weight in the InAs group once decreased to $122.24 \pm 21.11 \mathrm{~g}$, then increased slowly to the maximum level of $135.78 \pm 24.03 \mathrm{~g}$ at 16 $w \mathrm{k}$, that is $82.76 \%$ of the control group, and soon decreased in parallel to that of the control group. The difference in trends of body weight change between the InP group and the control group was also significant $(\mathrm{p}<0.05)$. Weight reduction in the $\mathrm{InP}$ group was less than in the InAs group ( $\mathrm{p}<0.0001$ ), the maximum level being $154.33 \pm 13.56 \mathrm{~g}$ at $16 \mathrm{wk}$, that is $94.07 \%$ of the control group. Although reduction in body weight and emaciation occurred in both InAs and InP groups, no systemic signs such as respiratory distress, dermatologic abnormality, behavioral or neurological disorder were observed.

\section{Serum levels of indium and arsenic}

Serum concentrations of indium and arsenic are shown in Fig. 2. At the termination of all instillations, serum indium levels were $7.62 \pm 1.43 \mu \mathrm{M}$ and $3.17 \pm 0.56 \mu \mathrm{M}$ in the InAs and InP groups, respectively. The serum concentration of indium in the InAs group was about twice as high as that in the InP group, in each period, the difference being significant $(p<0.0001)$. Indium was not detected in the sera of the control group. Serum indium had a biphasic pattern with an initial fast component and a subsequent slower component in both InAs and InP groups. The biological half-life of scrum indium in the InAs group was $2.5 \mathrm{wk}$ for the fast component, and 60.8 wk for the slower component. As for the InP group, the half-life was $6.2 \mathrm{wk}$ for the fast component and $60.0 \mathrm{wk}$ for the slower component.

In the InAs group, the serum arsenic concentration was continuously about $0.4 \mu \mathrm{M}$ from 0 to $88 \mathrm{wk}$ after treatment. In the InP and control groups, serum arsenic concentrations were very low. $0.05 \pm 0.01 \mu \mathrm{M}$ and 0.04 $\pm 0.00 \mu \mathrm{M}$, respectively.

\section{Histopathological changes in the lungs}

Absolute lung weights of both InAs and InP groups 


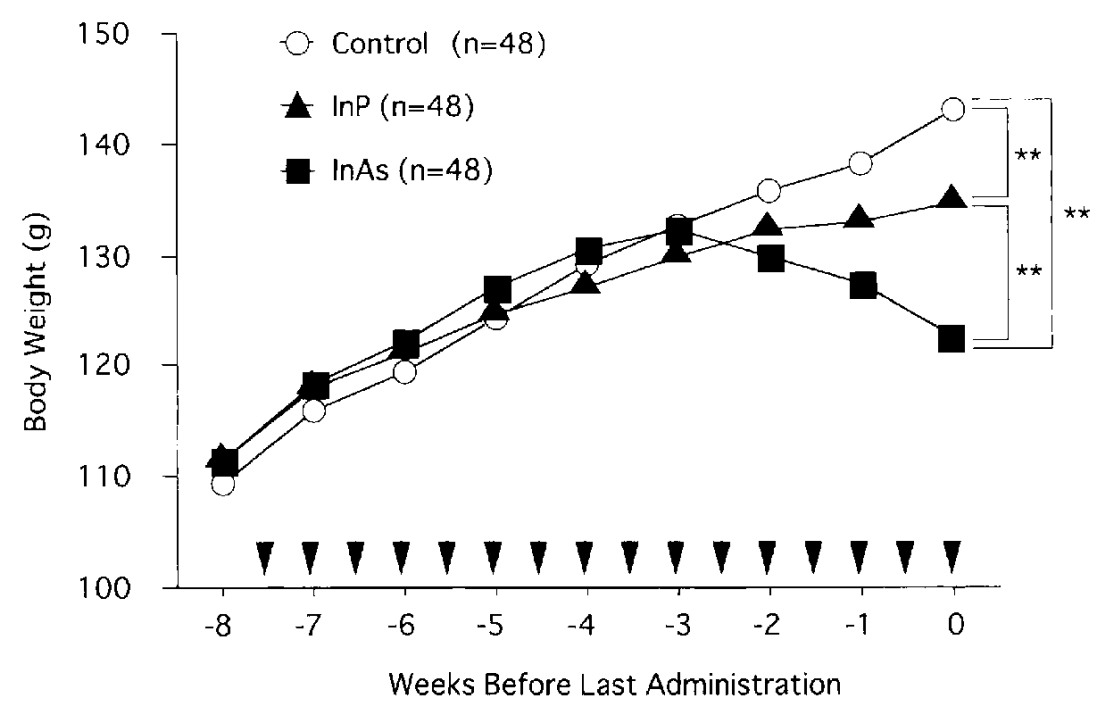

Fig. 1A. Change in body weight gain during administration period. Arrows indicate days of administration of these particles. The results are mean body weight of whole hamsters. Significant differences are indicated by $* *(p<0.01)$.

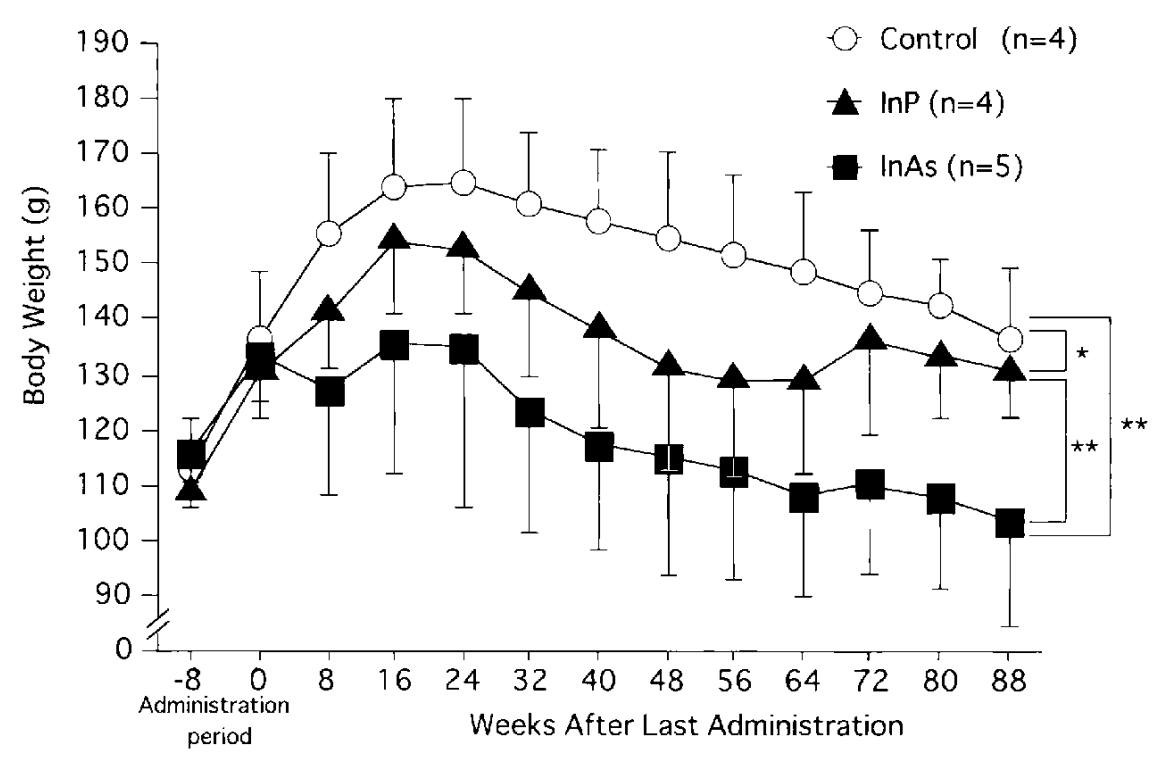

Fig. 1B. Change in body weight gain from the last administration. The results are shown as the mean \pm SD of hamsters euthanized at $88 \mathrm{wk}$. Significant differences are indicated by $*(0.01 \leq \mathrm{p}<0.05)$ and by $* *(\mathrm{p}<0.01)$.

were significantly higher than that of the control group at each time of measurement (data not shown). The severity of pathologic change in the lungs is shown in Table 1. Diffuse foci of moderate to severe inflammation were present in both InAs and InP groups during the observation period. At an early stage $(0,8,16 \mathrm{wk})$ in those two groups, extensive inflammatory foci in the lungs were scattered and consisted of alveolar septa diffusely lined with hyperplastic alveolar epithelium or regenerative epithelium with mild cellular atypia, and infiltration of inflammatory cells. Inflammatory cells mostly consisted of neutrophils mixed with macrophages, mononuclear cells, which were seen in the alveolar spaces, alveolar septum, bronchiolar lumen and peribronchiolar or perivascular tissues. These appeared in association with particles of In As and InP and subsequently changes to granuloma in alveolar septae and necrotic cell debris in alveolar spaces. From $16 \mathrm{wk}$, 


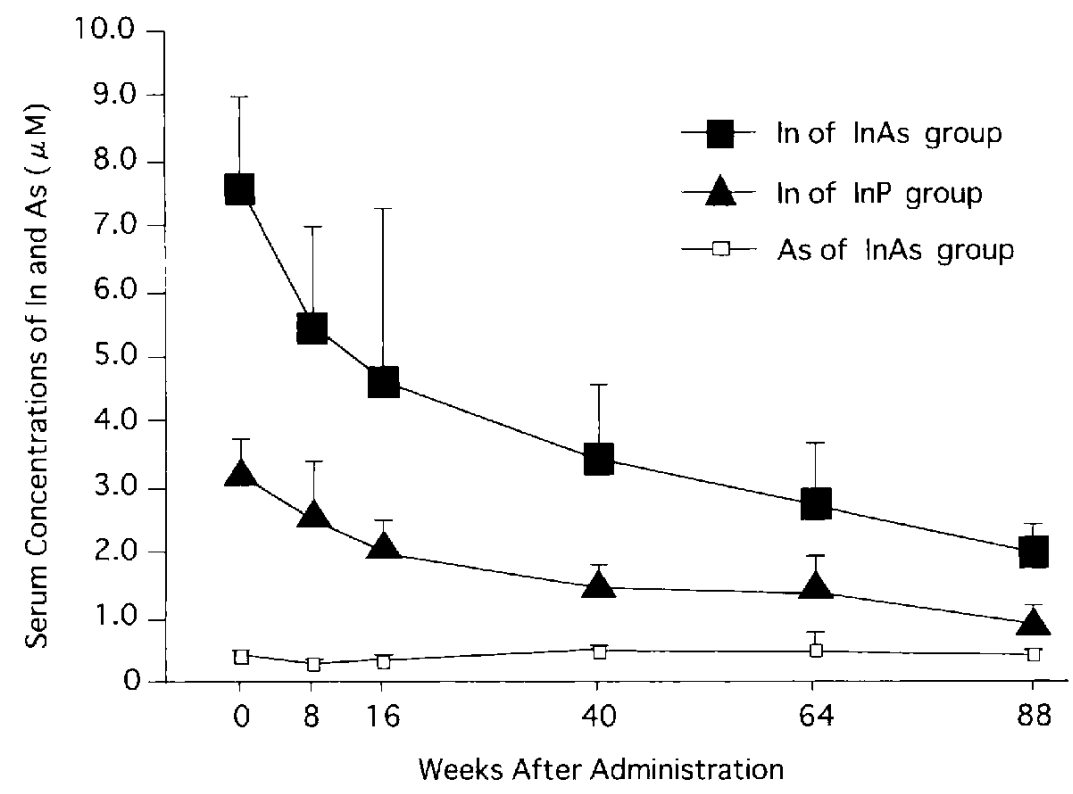

Fig. 2. Changes in molar concentrations of serum indium and arsenic. Serum indium concentrations were plotted for hamsters in the InAs and InP groups. Serum arsenic concentrations were plotted only for hamsters in the InAs group. The results are shown as the mean \pm SD.

Table 1. Pathological changes in the hamster lung after intratracheal instillation of InAs and InP.

\begin{tabular}{|c|c|c|c|c|c|c|c|}
\hline \multirow[b]{2}{*}{ Diffuse changes } & \multirow[b]{2}{*}{ Group } & \multicolumn{6}{|c|}{ Weeks after last administration (w) } \\
\hline & & 0 & 8 & 16 & 40 & 64 & 88 \\
\hline \multirow{3}{*}{$\begin{array}{l}\text { Inflammatory response with } \\
\text { diffuse hyperplasia of } \\
\text { bronchiolo-alveolar epithelium }\end{array}$} & InAs & +++ & +++ & +++ & +++ & +++ & ++ \\
\hline & InP & +++ & +++ & +++ & +++ & +++ & ++ \\
\hline & Control & \pm & - & - & - & - & - \\
\hline \multirow{3}{*}{ Interstitial fibrosis } & InAs & + & ++ & +++ & +++ & +++ & +++ \\
\hline & $\operatorname{InP}$ & + & ++ & +++ & +++ & +++ & +++ \\
\hline & Control & - & - & - & - & - & - \\
\hline & & \multicolumn{6}{|c|}{ Weeks after last administration (w) } \\
\hline Localized lesions & Group & 0 & 8 & 16 & 40 & 64 & 88 \\
\hline \multirow{3}{*}{$\begin{array}{l}\text { Localized hyperplasia of } \\
\text { bronchiolo-alveolar epithelium } \\
\text { with or without squamous cell } \\
\text { metaplasia }\end{array}$} & $\operatorname{In} A s$ & + & ++ & ++ & \pm & \pm & - \\
\hline & InP & + & ++ & ++ & \pm & \pm & - \\
\hline & Control & - & - & - & - & - & - \\
\hline \multirow{3}{*}{$\begin{array}{l}\text { Localized hyperplasia of } \\
\text { bronchiolo-alveolar epithelium } \\
\text { with PAS positive mucinous } \\
\text { exudation }\end{array}$} & In As & + & + & + & ++ & + & + \\
\hline & InP & \pm & ++ & ++ & ++ & ++ & ++ \\
\hline & Control & - & - & - & - & - & - \\
\hline Alveolar proteinosis-like & InAs & - & - & + & + & + & +++ \\
\hline lesion with PAS posilive & InP & - & - & + & ++ & ++ & +++ \\
\hline mucinous exudation & Control & - & - & - & - & - & - \\
\hline
\end{tabular}

Severity of the lung lesions was evaluated based on five grades: -; negative, \pm ; slight, + ; mild, ++; moderate, +++; severe. 
A

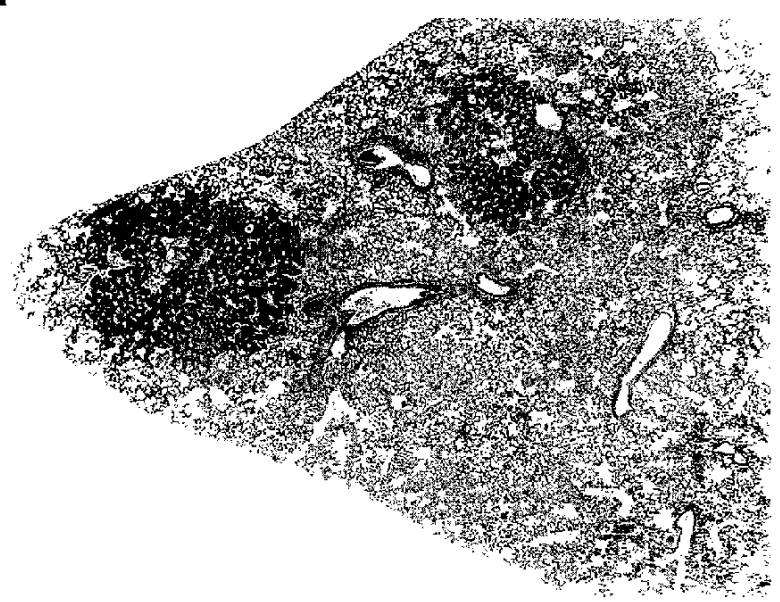

C

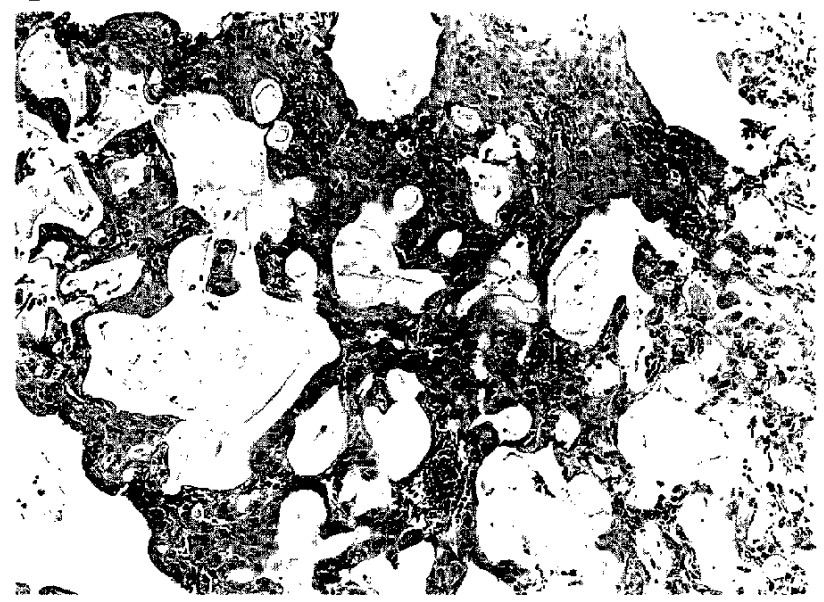

B

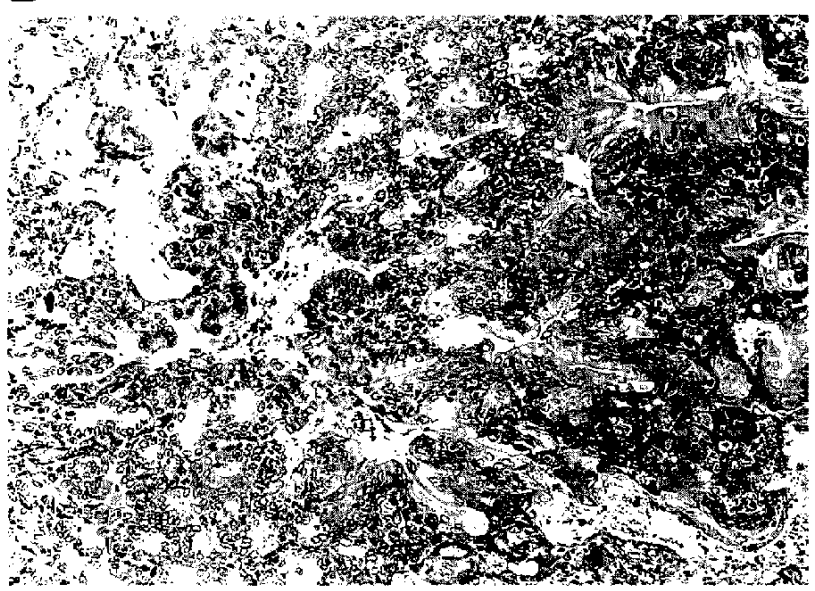

D

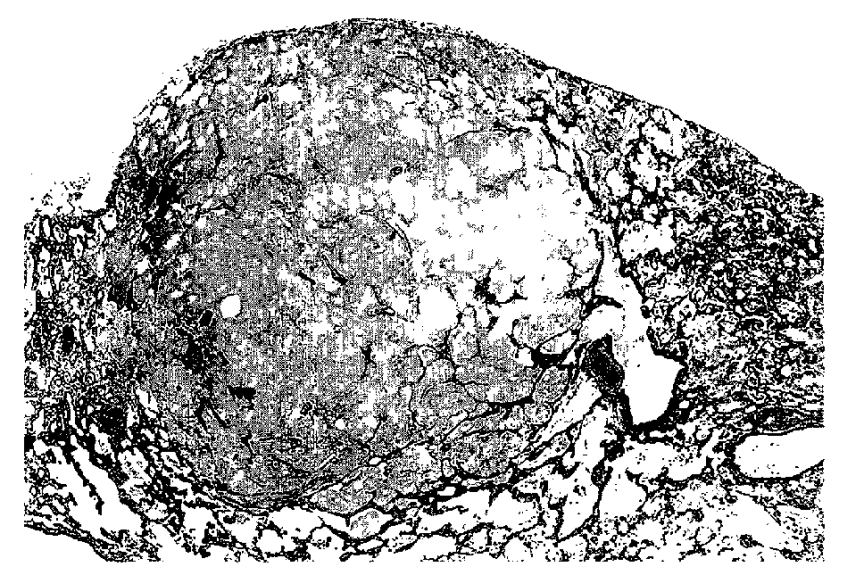

Fig. 3. (A) Low magnification photomicrograph of a hamster lung showing diffuse inflammatory change and two localized lesions in an InAs-group hamster just after termination of the final instillation. $\times 24$. (B) Pulmonary localized hyperplastic lesion in an InAs-group hamster consisting of cuboidal or tall-columnar epithelium with mild to moderate cellular atypia making focal tubular configuration just after instillation. Squamous cell metaplasia with keratinization is evident. $\times 200$. (C) Pulmonary localized lesion in an InAs-group hamster showing PAS positive exudation into bronchiolo-alveolar spaces of the localized hyperplastic lesion that appeared gradually after $16 \mathrm{wk} . \times 100$. (D) Pulmonary localized lesion in an InAsgroup hamster seen mainly after $40 \mathrm{wk}$ showing expanding bronchiolo-alveolar septae with a huge volume of PAS positive exudation, which we call a 'proteinosis-like lesion'. $\times 49$.

macrophages with an expanded cytoplasm were scattered about and included black particles. Bronchial epithelium also underwent diffuse hyperplastic or regenerative changes and thickened interstitial fibrosis from $16 \mathrm{wk}$. These severe inflammatory changes were continuous from 0 to $64 \mathrm{wk}$.

Pulmonary localized lesions with hyperplastic or regenerative bronchiolo-alveolar epithelium with mild cellular atypia appeared in every lobe of both InAs and InP groups from termination of the treatment. as shown in Figs. 3A and B. These lesions were observed sporadically throughout the observation period and their distribution was not associated with the degree of inflammation. Localized lesions in the In As and InP groups were the same morphologically and changed gradually, as mentioned below. From 0 to $16 \mathrm{wk}$, they consisted of a cuboidal or tall-columnar epithelium with mild to moderate cellular atypia, mostly hyperplasia, seen as a focal tubular configuration. Glandular constructions with squamous cell metaplasia and finally keratinization in alveolar spaces were evident. The hyperplastic and metaplastic cells spread within alveolar spaces and alveolar constructions remained intact. The true capsule of the lesions was absent and the edges were poorly defined. From 8 wk, PAS positive mucinous exudation formed in the inner space of the localized lesions (Fig. 3C). After $16 \mathrm{wk}$, there were alveolar proteinosis-like 


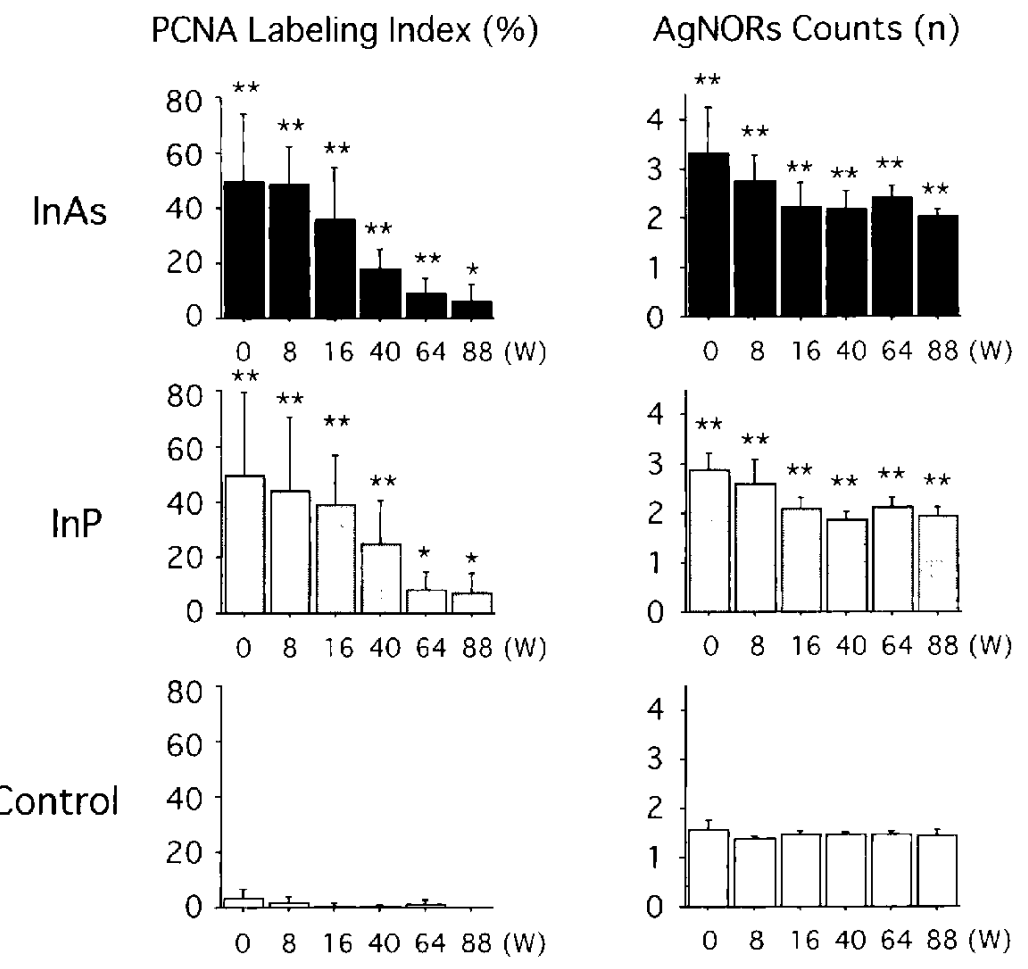

Fig. 4. Change in the level of proliferative activity demonstrated by PCNA labeling index and AgNORs count. The results are shown as the mean \pm SD. Significant differences from the control group are indicated by $*(0.01 \leq p<0.05)$ and by $* *(p<0.01)$.

lesions with expanding. huge PAS positive exudation surrounded by alveolar septa lined with flat cpithelium, as described earlier ${ }^{261}$ (Fig. 3D). Findings of neoplastic changes were nil throughout the experiment.

\section{Proliferative activity of pulmonary localized hyperplastic lesions}

Proliferating changes were evaluated with two known markers (Fig. 4). Expressions of the PCNA protein were evident on the nuclei of bronchiolo-alveolar cells, mostly in the localized hyperplastic lesions and sparsely in the severely inflamed areas. As in the inflamed areas, L.I. of PCNA varied according to the severity of the inflammation, and could not be evaluated to compare with the L.I. of localized lesions. In both the InAs and InP groups. L.I. was significantly higher in the localized lesion than in normal tissue all the time, but gradually diminished. AgNORs counts for the localized lesions in both InAs and InP groups were significantly higher than for normal tissues of the control group all the time and tended to decrease with time. Between the InAs group and InP group, differences in neither PCNA L.I. nor AgNORs were significant in each period.

When we evaluated the genomic mutation of codons 12. 13 of the $\mathrm{K}$-ras gene in DNAs isolated from the microdissected samples of all the pulmonary localized lesions of InAs and InP-treated hamsters, no mutation in any codon of the K-ras gene was evident in any of the lesions examined (Fig. 5).

\section{Discussion}

In a previous work. 14 times we instilled $7.7 \mathrm{mg} / \mathrm{kg}$ InAs intratracheally into hamsters, which could not be observed for more than 2 months because of severe emaciation ${ }^{15}$. We set the instillation dose of indium particles at about a half the dose used in the last work for the present study and this is apparently the first report to evaluate the long-term systemic and pulmonary toxicity of indium compounds.

Indium was readily detected in sera of hamsters in both InAs and InP groups. In the InAs group, serum concentrations of indium just after instillation were 7.62 $\pm 1.43 \mu \mathrm{M}$. Whereas in our previous study, in which about twice the dose of InAs was instilled intratracheally, $19.47 \pm 6.54 \mu \mathrm{M}$ of indium was detected in the seralt?. These results suggest that instilled InAs particles dissolve into serum in a dose dependent manner. Serum indium in both groups had a biphasic excretion pattern after intratracheal instillation of particles. Concerning the second component of serum indium. indium is eliminated 


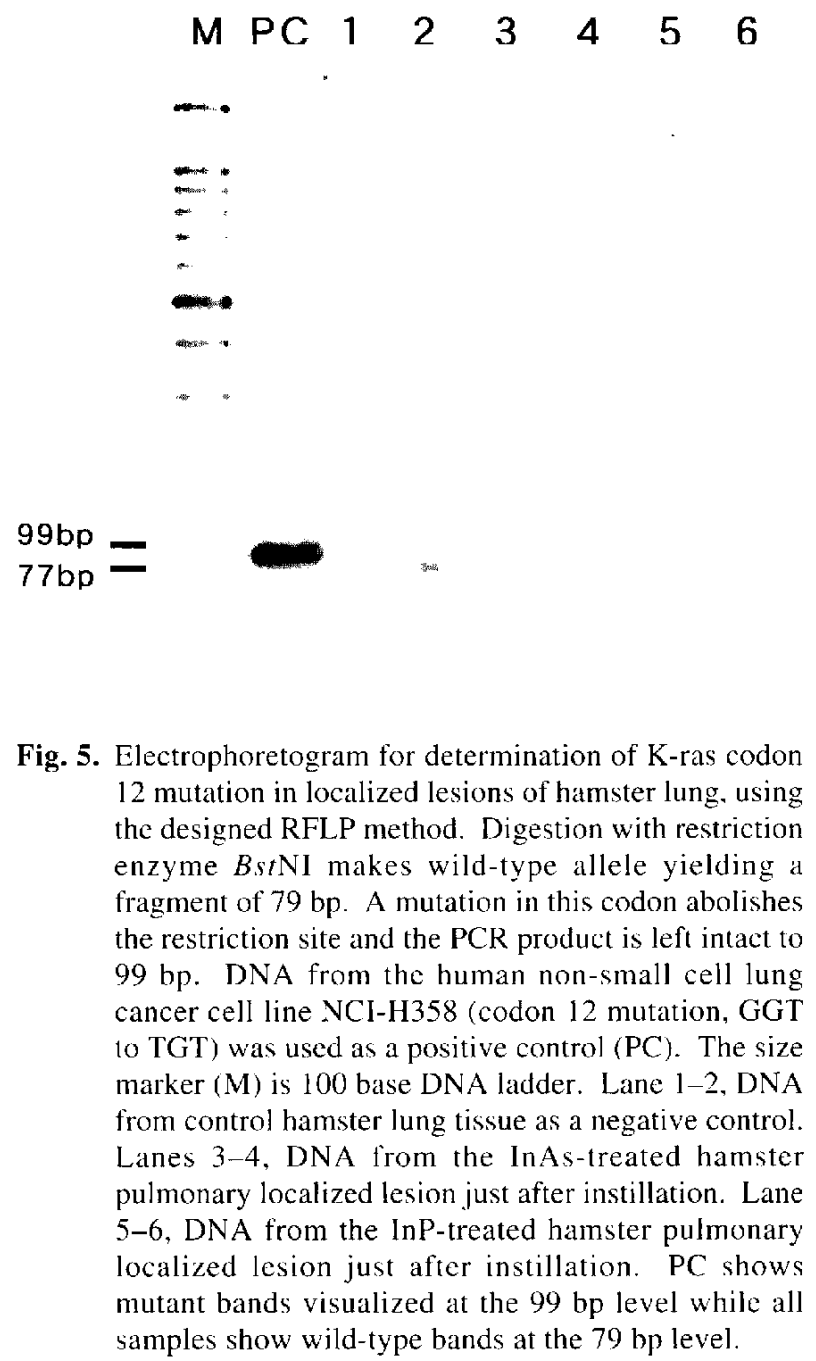

slowly from the serum and remains long in the body. Chronic effects on the body must be given attention to if exposed to these particles.

An equimolar amount of the two indium compounds was administered intratracheally and the serum indium level in the InAs group was about double that in the InP group. To explain the possible cause of the difference between serum indium levels in the InAs and InP groups, the amount of indium influx into serum from the lungs and indium outflow from serum must be taken into account. In these two groups, the rates of elimination from scrum are supposed to be the same because the half life periods of serum indium in the slower component were the same. The difference in the amount of influx between InAs and InP particles is also speculated to be the basis of the difference. Measuring the pulmonary clearances of these indium particles will clarify the basis.

The toxicity of insoluble particles generally depends on the physical effect of the particles themselves or the chemical properties of dissolved elements, or both.
Concerning the effects of InAs or InP particles, repetitive intratracheal instillations lead to accumulation of these particles in the bronchiolo-alveolar spaces and alveolar septae. Respiratory disorders such as airway obstruction, pulmonary intlammation or fibrosis would be expected to inhibit regular growth of animals. The total amounts of particles administered, which were higher in the InAs group than in the $\mathrm{InP}$ group, may correlate to the disparity in body weight reduction. Accumulated indium particles in the hamster lungs dissolve and a dissolved form of indium was found in the serum. This indium in the blood circulation is a great potential health risk, as demonstrated by severe emaciation. Weight reduction was severe in the InAs group, particularly in the early period, and it correlated with serum indium concentrations so that serum indium might be related to growth inhibition concentration dependently. Although arsenic is considered to be eliminated immediately from the serum ${ }^{6.27)}$, low levels were constantly sustained. Phosphorus in InP is biologically essential, whereas arsenic in InAs is known to be toxic. Arsenic in the serum may be partly associated with body weight reduction in the InAs group.

As for pulmonary lesions, repeated intratracheal instillations of $\mathrm{GaAs}$ into the hamster lung induced severe lung damage during a 2-yr examination period but lung tumors and hyperplastic lesions were never evident ${ }^{28}$. In the present study, severe pulmonary inflammations and lung weight gain, a sign of a continuing inflammatory response, were observed in both the InAs and InP groups throughout the experiment. In addition, pulmonary localized hyperplastic lesions were observed in both InAs and InP groups. The lesions were almost the same morphologically in the two groups and no obvious difference in severity or frequency was observed, although $\ln$ As contains arsenic, a potent carcinogen in human lungs $\mathrm{s}^{29}$. Data on arsenic-induced lung carcinogenicity in rodents was not comparable to human

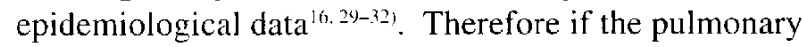
localized lesion is induced by unique chemical properties of dissolved elements, the main cause of the lesion is not arsenic but indium.

When lung tissue is exposed by poorly soluble particles, recruitment and activation of inflammatory cells induce untoward effects, including cell proliferation and mutations in crucial oncogenes ${ }^{33}$. Although retained particles of InAs or InP were microscopically observed around the pulmonary hyperplastic lesions, PAS-positive mucinous exudation was excessive from $16 \mathrm{wk}$ and the lesions transformed morphologically to proteinosis-like lesions rather than to neoplastic tumors. A correlation between the pathogenesis of proteinosis and cancer was indicated by continuous stimulation by insoluble particles $^{34 t}$. We suggest that persistent stimulation by accumulated particles induces localized hyperplastic lesions that subsequently produce aberrant proteins, but 
the stimuli are not sufficient to induce neoplastic changes.

To closely examine from another point of view if the pulmonary lesions have preneoplastic activities, we used biological markers that indicate cell proliferation or neoplastic activity. Binding of a specific antibody to PCNA and staining of AgNORs were used to investigate the proliferative activity of cells. The use of both is feasible in the case of chemically induced tumors in hamsters ${ }^{35.36)}$. Although the levels gradually decreased, PCNA protein expression and AgNORs activity were prominent in the pulmonary localized lesions throughout the examination. The cell proliferative activity of these indium compounds on bronchiolo-alveolar cells is thus confirmed, although it is only temporary. K-ras is a potent proto-oncogene and considered to be an indicator of direct genoloxicity and preneoplastic activity. Mutations in codons 12,13 and 61 of the gene were found in several human cancers, especially adenocarcinoma of the pancreas, lung and colon cancers ${ }^{37}$. This gene is well conserved throughout generations and is activated in many types of chemically-induced rodent tumors ${ }^{24.38-40)}$. In the hamster lung, high frequency mutations in K-ras codon 12 and 13 in lung tumors were found to be induced by chemical carcinogens such as $\mathrm{N}$-nitroso compounds ${ }^{41-4.3}$. We investigated the status of the K-ras gene in all the pulmonary localized lesions but no mutation was observed. Our study revealed increased expression of PCNA and AgNORs activation indicating continuing cell proliferation. It was reported that indium affects several kinds of gene expression and protein production in vitro and in vivo $o^{x .4451}$, but no evidence of genotoxicity was obtained and the basis for the increased cell proliferation in the pulmonary localized lesions remains to be explained. Mechanisms involved in cell proliferation, as induced by these indium compounds, requires further study.

In conclusion, InAs and InP particles are toxic when repeated intratracheal instillations are given to hamsters, and InAs has greater systemic effects than does InP. Dissolved indium and the particles of indium compounds are considered to play crucial roles in causing pulmonary localized lesions with proliferative activities. The biological cffects of these semiconductor materials warrant further investigation.

Acknowledgment: This study was supported in part by Grant No.10670317 from the Ministry of Education, Sciences, Sports and Culture, Japan. And we thank Mrs. M. Ohara for language assistance.

\section{References}

1) Ishiguro $\mathrm{S}$. Industries using arsenic and arsenic compounds. Appl Organomet Chem 1992; 6: 323-331.

2) Robinson AL. GaAs readied for high-speed microcircuits. Science 1983: 219:275-277.
3) Webb DR, Wilson SE, Carter DE. Pulmonary clearance and toxicity of respirable gallium arsenide particulates intratracheally instilled into rats. Am Ind Hyg Assoc J 1987; 48: 660-667.

4) Webb DR, Wilson SE, Carter DE. Comparative pulmonary toxicity of gallium arsenide, gallium (III) oxide, or arsenic (III) oxide intratracheally instilled into rats. Toxicol Appl Pharmacol 1986; 82: 405-416.

5) Goering PL, Maronpot RR, Fowler BA. Effect of intratracheal gallium arsenide administration on deltaaminolevulinic acid dehydratase in rats: relationship to urinary excretion of aminolevulinic acid. Toxicol Appl Pharmacol 1988; 92: 179-193.

6) Yamauchi H, Fowler BA. Toxicity and metabolism of inorganic and methylated arsenicals. In; JO Nriagu, ed. Arsenic in the environment Part II: Human health and ecosystem effects. New York: John Wiley \& Sons. INC., 1994: 35-53.

7) Yamauchi H, Takahashi K, Yamamura Y, Fowler BA. Metabolism of subcutaneous administered indium arsenide in the hamster. Toxicol Appl Pharmacol 1992: 116: 66-70.

8) Conner EA, Yamauchi H, Fowler BA. Alterations in the heme biosynthetic pathway from the III-V semiconductor metal, indium arsenide (InAs). Chem Biol Interact 1995: 96: 273-285.

9) Zheng W, Winter SM, Kattnig MJ, Carter DE, Sipes IG. Tissue distribution and elimination of indium in male Fischer 344 rats following oral and intratracheal administration of indium phosphide. J Toxicol Environ Health 1994; 43: 483-494.

10) Kabe I, Omac K, Nakashima H, et al. In vitro solubility and in vivo toxicity of indium phosphide. J Occup Health 1996; 38: 6-12,

11) Oda K. Toxicity of a low level of indium phosphide (InP) in rats after intratracheal instillation. Industrial Health 1997; 35: 61-68.

12) Uemura $T$, Oda K, Omae K, et al. Effects of intratracheally administered indium phosphide on male Fischer 344 rats. J Occup Health 1997: 39: 205-210.

13) Hirata M, Tanaka A, Omura M. Makita Y, Inoue N. Metabolism and toxicity of gallium arsenide and indium arsenide by repetitive intratracheal instillation. Biomed Res Trace Element 1997; 8: 317-318 (in Japanese).

14) Omura M, Hirata M, Tanaka A, et al. Testicular toxicity evaluation of arsenic-containing binary compound semiconductors, gallium arsenide and indium arsenide. in hamsters. Toxicol Lett 1996; 89: 123-129.

15) Tanaka A. Hirata M. Omura M, et al. Comparative toxic study of the effect of gallium arsenide, indium arsenide and arsenic trioxide following intratracheal instillations to the lung of Syrian golden hamsters. Fukuoka Acta Medica 2000; $91: 21-33$.

16) Ishinishi N, Yamamoto A, Hisanaga A, Inamasu T. Tumorigenicity of arsenic trioxide to the lung in Syrian golden hamsters by intermittent instillations. Cancer Lett 1983;21: 141-147.

17) Iatropoulos MJ, Williams GM. Proliferation markers. Exp Toxicol Pathol 1996; 48: 175-181. 
18) Sunday ME, Willett CG, Patidar K, Graham SA. Modulation of oncogene and tumor suppressor gene expression in a hamster model of chronic lung injury with varying degrees of pulmonary neuroendocrine cell hyperplasia. Lab Invest 1994; 70: 875-888.

19) Sunday ME, Willett CG, Graham SA, Oreffo VI, Linnoila RI, Witschi H. Histochemical characterization of non-neuroendocrine tumors and neuroendocrine cell hyperplasia induced in hamster lung by 4 (methylnitrosamino)-1-(3-pyridyl)-1-butanone with or without hyperoxia. Am J Pathol 1995; 147: 740-752.

20) Thaete LG, Ahnen DJ, Malkinson AM. Proliferating cell nuclear antigen (PCNA/cyclin) immunocytochemistry as a labeling index in mouse lung tissues. Cell Tissue Res 1989; 256: 167-173.

21) Ploton $D$, Menager $M$, Jeannesson $P$, Himber G, Pigeon $\mathrm{F}$, Adnet JJ. Improvement in the staining and in the visualization of the argyrophilic proteins of the nucleolar organizer region at the optical level. Histochem J 1986; 18: 5-14.

22) Crocker J, Boldy DA, Egan MJ. How should we count AgNORs? Proposals for a standardized approach. J Pathol 1989; 158: 185-188.

23) Howat AJ, Giri DD, Cotton DW, Slater DN. Nucleolar organizer regions in Spitz nevi and malignant melanomas. Cancer 1989; 63: 474-478.

24) Sugio K, Gazdar AF, Albores-Saavedra J, Kokkinakis DM. High yields of K-ras mutations in intraductal papillary mucinous tumors and invasive adenocarcinomas induced by $\mathrm{N}$-nitroso(2hydroxypropyl)(2-oxopropyl)amine in the pancreas of female Syrian hamsters. Carcinogenesis 1996; 17: 303309.

25) Sugio K, Kishimoto Y, Virmani AK, Hung JY, Gazdar $\mathrm{AF}$. K-ras mutations are a relatively late event in the pathogenesis of lung carcinomas. Cancer Res 1994; 54: 5811-5815.

26) Tanaka A, Hisanaga A, Hirata M, Omura M, Inoue N, Ishinishi N. Pulmonary toxicity of indium arsenide and arsenic selcnid following repeated intratracheal instillations to the lungs of hamsters. Appl Organomet Chem 1994; 8: 265-271.

27) Fowler BA. Indium. In: L Friberg, GF Nordberg and $\mathrm{V}$ Vouk, eds. Handbook on the Toxicology of Metals, 2nd edition. Amsterdam: Elsevier, 1986: 267-275.

28) Ohyama S, Ishinishi N, Hisanaga A, Yamamoto A. Comparative chronic toxicity, including tumorigenicity, of gallium arsenide and arsenic trioxide intratracheally instilled into hamsters. Appl Organomet Chem 1988; 2: 333-337.

29) IARC. Arsenic and arsenic compounds (Group1). In: IARC Monographs on the evaluation of carcinogenic risk to humans. Lyon, France: World Health Organization, 1987: 100-106.

30) Pershagen $G$. The carcinogenicity of arsenic. Environ Health Perspect 1981; 40: 93-100.

31) Yamamoto A, Hisanaga A, Ishinishi N. Tumorigenicity of inorganic arsenic compounds following intratracheal instillations to the lungs of hamsters. Int J Cancer 1987; 40: 220-223.

32) Axelson O. Arsenic compounds and cancer. J Toxicol Environ Health 1980; 6: 1229-1235.

33) Driscoll KE. Role of inflammation in the development of rat lung tumors in response to chronic particle exposure. Inhal Toxicol 1996; 8: 139-153.

34) Friemann J, Pott F, Wilk KB, et al. Pulmonary alveolar proteinosis in rats after administration of quartz: Its possible role in morphogenesis of lung cancer. J Cancer Res Clin Oncol 1994; 120: 348-353.

35) Sato M, Furukawa F, Nishikawa A, Mitsumori K, Imazawa T, Takahashi M. Analysis of proliferative activity in renal lesions induced by $\mathrm{N}$-nitrosobis(2oxopropyl)amine (BOP) in male Syrian golden hamsters. Cancer Lett 1994; 79: 91-99.

36) Yoshimi N, Gimenez-Conti IB, Slaga TJ. Morphological changes of the nucleolar organizer regions induced by 7,12-dimethylben $\_$[a] anthracene in the hamster cheek pouch. J Oral Pathol Med 1993; 22: 97-100.

37) Bos JL. ras oncogenes in human cancer: a review. Cancer Res 1989; 49: 4682-4689.

38) Cerny WL, Mangold KA, Scarpelli DG. K-ras mutation is an early event in pancreatic duct carcinogenesis in the Syrian golden hamster. Cancer Res 1992; 52: 4507 4513.

39) Ichikawa T, Yano Y, Uchida M, Otani S, Hagiwara K, Yano $\mathrm{T}$. The activation of K-ras gene at an early stage of lung tumorigenesis in mice. Cancer Lett 1996; 107: $165-170$.

40) Tsutsumi $M$, Kondoh $S$, Noguchi $O$, et al. K-ras gene mutation in early ductal lesions induced in a rapid production model for pancreatic carcinomas in Syrian hamsters. Jpn J Cancer Res 1993; 84: 1101-1105.

41) Oreffo VI, Lin HW, Padmanabhan R, Witschi H. Kras and $\mathrm{p} 53$ point mutations in 4-(methylnitrosamino)1-(3-pyridyl)-1-butanone-induced hamster lung tumors. Carcinogenesis 1993; 14: 451-455.

42) Baskaran K, Laconi S, Reddy MK. Transformation of hamster pancreatic duct cells by 4(methylnitrosamino)-1-(3-pyridyl)-1-butanone (NNK), in vitro. Carcinogenesis 1994; 15: 2461-2466.

43) Ning $\mathrm{H}$, Oreffo VI, Gumerlock PH, Witschi H. Increased c-Ki-ras expression in hamster lung exposed to $\mathrm{N}$-nitrosodiethylamine and hyperoxia as detected by the polymerase chain reaction. Cancer Lett 1991; 59: 75-80.

44) Aoki Y, Lipsky MM, Fowler BA. Alteration in protein synthesis in primary cultures of rat kidney proximal tubule epithelial cells by exposure to gallium, indium, and arsenite. Toxicol Appl Pharmacol 1990; 106: 462468.

45) Bustamante J, Dock L, Vahter M, Fowler B, Orrenius S. The semiconductor elements arsenic and indium induce apoptosis in rat thymocytes. Toxicology 1997; 118 : $129-136$. 